\title{
Deep inspiration avoidance and airway response to methacholine: Influence of body mass index
}

\author{
Louis-Philippe Boulet MD FRCPC, Hélène Turcotte MSc, Geneviève Boulet DEC, \\ Barbara Simard BSc, Patricia Robichaud BSc
}

\begin{abstract}
L-P Boulet, H Turcotte, G Boulet, B Simard, P Robichaud. Deep inspiration avoidance and airway response to methacholine: Influence of body mass index. Can Respir J 2005;12(7):371-376.
\end{abstract}

OBJECTIVE: To evaluate the effects of deep inspiration avoidance response to methacholine inhalation in 23 nonobese (body mass index between $18 \mathrm{~kg} / \mathrm{m}^{2}$ and $30 \mathrm{~kg} / \mathrm{m}^{2}$ ) and 27 obese (body mass index $30 \mathrm{~kg} / \mathrm{m}^{2}$ or greater), nonatopic, nonasthmatic normal subjects. METHODS: Each subject had four methacholine challenges. In tests $\mathrm{A}$ and $\mathrm{B}$, the first postmethacholine forced expiratory volume in $1 \mathrm{~s}\left(\mathrm{FEV}_{1}\right)$ was measured at $30 \mathrm{~s}$ and $3 \mathrm{~min}$ postinhalation, respectively; tests $\mathrm{C}$ and $\mathrm{D}$ were single-dose tests (using the final dose of test $\mathrm{B}$ ), with the first postmethacholine $\mathrm{FEV}_{1}$ being obtained at $3 \mathrm{~min}$, without (test C) or with (test D) 20 min of deep inspiration avoidance before inhalation.

RESULTS: The mean provocative concentrations inducing a $20 \%$ fall in $\mathrm{FEV}_{1}$ on tests $\mathrm{A}$ and $\mathrm{B}$ were $80.6 \mathrm{mg} / \mathrm{mL}$ and $28.5 \mathrm{mg} / \mathrm{mL}$ $(\mathrm{P}<0.0001)$ in nonobese subjects, respectively, and $56.3 \mathrm{mg} / \mathrm{mL}$ and $21.5 \mathrm{mg} / \mathrm{mL}(\mathrm{P}<0.0001)$ in obese subjects, respectively. No significant differences were observed in test $\mathrm{A}$ or $\mathrm{B}$ between control and obese subjects. Mean falls in $\mathrm{FEV}_{1}$ for tests $\mathrm{C}$ and $\mathrm{D}$ were $20.3 \%$ and $40.0 \%$ $(\mathrm{P}=0.0003)$ in nonobese subjects, respectively, and $18.5 \%$ and $23.6 \%$ $(\mathrm{P}>0.05)$ in obese subjects, respectively.

CONCLUSIONS: As previously observed in patients with asthma, the present study found that nonasthmatic obese subjects had no increase in the fall in $\mathrm{FEV}_{1}$ after deep inspiration avoidance before methacholine, whereas nonobese subjects did, suggesting that obesity alters airway function. No significant changes were found between groups for symptom perception.

Key Words: Airway responsiveness; Asthma; Deep inspiration; Methacholine

Several studies $(1,2)$ have reported an increased prevalence Oof asthma or asthma-like symptoms in obese subjects. As a corollary, weight loss has been associated with an improvement in lung function and a reduction in asthma severity $(3,4)$. However, it is still unclear how obesity affects airway function and asthma severity. Among the possibilities proposed in a recently published National Heart, Lung, and Blood Institute Workshop report (5) on obesity and asthma were increased inflammatory response to various stimuli, increased tendency to develop allergies, neurogenic mechanisms and possible mechanical factors. With regard to these last factors, reduced airway distention during inspiratory manoeuvres and loss of airway smooth muscle (ASM) stretch-relaxation have been considered, as has also been suggested in patients with asthma (6).

\section{Effets de l'absence d'inspirations profondes sur la réponse bronchique à la métacholine : Influence de l'indice de masse corporelle}

\begin{abstract}
OBJECTIF : Évaluer les effets de l'absence d'inspirations profondes sur la réponse à la métacholine chez des sujets normaux sans allergie et san asthme : 23 non-obèses $\left(18 \mathrm{~kg} / \mathrm{m}^{2}<\right.$ indice de masse corporelle $\left.<30 \mathrm{~kg} / \mathrm{m}^{2}\right)$ et 27 obèses (indice de masse corporelle $\geq 30 \mathrm{~kg} / \mathrm{m}^{2}$ ).

MÉTHODES : Les sujets ont eu quatre tests de provocation bronchique à la métacholine. Lors des tests $\mathrm{A}$ et $\mathrm{B}$, pendant lesquels des doses croissantes de métacholine étaient inhalées, la première mesure du volume expiratoire maximal en une seconde (VEMS) était prise, respectivement, 30 s et 3 min après la fin de chaque inhalation. Lors des tests $\mathrm{C}$ et $\mathrm{D}$ (tests de provocation à dose unique avec la dose finale du test $\mathrm{B}$ ), la première mesure de VEMS était obtenue 3 min après la fin de l'inhalation de métacholine. Ces derniers tests étaient précédés, soit d'une période de 20 min sans restriction respiratoire (test C) ou d'une période de 20 min sans inspiration profonde (test D). RÉSULTATS : La concentration moyenne provoquant une chute de $20 \%$ du VEMS était de $80,6 \mathrm{mg} / \mathrm{mL}$ après le test $A$ et de $28,5 \mathrm{mg} / \mathrm{mL}$ après le test $B(p<0,0001)$ chez les sujets non-obèses, et de $56,3 \mathrm{mg} / \mathrm{mL}$ et $21,5 \mathrm{mg} / \mathrm{mL}(\mathrm{p}<0,0001)$ chez les sujets obèses. Il n'y avait pas de différence significative entre les groupes pour la $\mathrm{CP}_{20}$ observée au test $\mathrm{A}$ ou au test $\mathrm{B}$. Les pourcentages de la chute moyenne du VEMS au test $C$ et au test $D$ étaient de 20,3\% and 40,0\% ( $\mathrm{p}=0,0003)$ chez les sujets non-obèses, et de $18,5 \%$ et $23,6 \%(p>0,05)$ chez les sujets obèses.

CONCLUSION : Le principal point d'intérêt de cette étude est que, tel qu'observé précédemment chez les sujets asthmatiques, les sujets obèses n'ont pas d'augmentation de chute du VEMS en l'absence de prise d'inspirations profondes précédant la provocation à la métacholine alors que les sujets non-obèses, dans les mêmes conditions, voient leur VEMS diminuer de façon significative, suggérant que l'obésité affecte la fonction respiratoire. Aucune différence significative n'a été observée entre les groupes en ce qui a trait à la perception des symptômes induits.
\end{abstract}

It has indeed been proposed that the failure to regularly stretch the ASM can result in a potentially hyperresponsive state for the muscle $(7,8)$. Healthy subjects do not develop airway narrowing in response to bronchoconstrictor agents (agents that induce bronchoconstriction in asthmatic patients) but do develop an exaggerated airway responsiveness when they avoid deep inspirations $(8,9)$. In patients with asthma, however, deep inspirations have little or no influence on the airway response to methacholine.

Limited information is available on the influence of obesity on airway responses to bronchoconstrictor agents. In attempting to elucidate the possible influences of obesity on airway function, we hypothesized that obesity is associated with an altered airway response in the form of a reduced influence of deep 
TABLE 1

Subjects' characteristics

\begin{tabular}{|c|c|c|c|}
\hline Parameter & $\begin{array}{l}\text { Nonobese subjects } \\
\mathrm{BMI}<30 \mathrm{~kg} / \mathrm{m}^{2}(\mathrm{n}=23)\end{array}$ & $\begin{array}{c}\text { Obese subjects } \\
\mathrm{BMI} \geq 30 \mathrm{~kg} / \mathrm{m}^{2}(\mathrm{n}=27)\end{array}$ & $P$ \\
\hline Sex, men/women & $4 / 19$ & $5 / 22$ & \\
\hline $\begin{array}{l}\text { Mean age, years } \\
\text { (range) }\end{array}$ & $\begin{array}{c}32.2 \\
\text { (19 to } 59)\end{array}$ & $\begin{array}{c}34.6 \\
\text { (21 to } 50)\end{array}$ & $>0.05$ \\
\hline \multicolumn{4}{|l|}{$\mathrm{FEV}_{1}, \%$ predicted } \\
\hline $\begin{array}{l}\text { Mean } \pm \text { SEM } \\
\quad(\text { range })\end{array}$ & $\begin{array}{l}103.9 \pm 2.3 \\
\text { (87 to } 122)\end{array}$ & $\begin{array}{l}97.9 \pm 3.0 \\
\text { (70 to } 147)\end{array}$ & $>0.05$ \\
\hline \multicolumn{4}{|l|}{ FVC, \% predicted } \\
\hline $\begin{array}{l}\text { Mean } \pm \text { SEM } \\
\quad \text { (range) }\end{array}$ & $\begin{array}{l}104.4 \pm 1.6 \\
(90 \text { to } 119)\end{array}$ & $\begin{array}{c}98.6 \pm 3.0 \\
\text { (72 to } 147)\end{array}$ & $>0.05$ \\
\hline $\begin{array}{l}\text { Mean } \mathrm{PC}_{20}, \mathrm{mg} / \mathrm{mL} \\
( \pm \mathrm{SEM}) \\
\text { (range) }\end{array}$ & $\begin{array}{c}80.6 \\
(65.9 \text { to } 98.7) \\
(16 \text { to }>128)\end{array}$ & $\begin{array}{c}56.3 \\
(47.5 \text { to } 67.0) \\
(9 \text { to }>128)\end{array}$ & $>0.05$ \\
\hline $\begin{array}{l}\text { Mean BMI, kg/m² } \\
\text { (range) }\end{array}$ & $\begin{array}{c}22.3 \\
\text { (18 to } 28)\end{array}$ & $\begin{array}{c}37.3 \\
\text { (30 to } 49)\end{array}$ & $<0.0001$ \\
\hline
\end{tabular}

BMI Body mass index; FEV 1 Forced expiratory volume in $1 \mathrm{~s}$; FVC Forced vital capacity; $P C_{20}$ Provocative concentration inducing a $20 \%$ fall in FEV 1

inspiration on the methacholine response. Among other factors that potentially modulate the airway response to methacholine is the time of the first forced expiratory volume in $1 \mathrm{~s}$ $\left(\mathrm{FEV}_{1}\right)$ after the first inhalation of methacholine. We previously described that when the first $\mathrm{FEV}_{1}$ was obtained at 3 min compared with $0.5 \mathrm{~min}$ postmethacholine, there was an increased airway response to methacholine in both normal and asthmatic subjects, although it was more marked in the latter group (10).

The goal of the present study was to determine whether obese subjects, in comparison with nonobese subjects, have changes in airway responses similar to those found in asthma. We therefore looked at the influence of avoidance of deep inspirations before or after methacholine inhalation on airway response. We also investigated whether the perception of symptoms was different between obese and nonobese subjects.

\section{METHODS}

\section{Subjects}

Subjects were enrolled from advertisements in local newspapers and at Laval University, Ste-Foy, Quebec. Fifty nonatopic, nonsmoking subjects who had normal airway responsiveness (ie, the provocative concentration of methacholine inducing a 20\% fall in $\mathrm{FEV}_{1}\left[\mathrm{PC}_{20}\right]$ was greater than $8 \mathrm{mg} / \mathrm{mL}$ ) (Table 1 ) were enrolled (11). The group was divided into 23 nonobese (body mass index [BMI] less than $30 \mathrm{~kg} / \mathrm{m}^{2}$ ) and 27 obese subjects (BMI $30 \mathrm{~kg} / \mathrm{m}^{2}$ or greater) (12). All subjects were nonsmokers and none had ever had a diagnosis of asthma or reported respiratory symptoms consistent with asthma. They showed no evidence of other pulmonary disease and had no contraindication to the tests. None of the subjects reported respiratory airway infection in the month preceding the study. The study was approved by an institutional ethics committee. All subjects signed an informed consent form.

\section{Study design}

A previously developed study design was used that was originally developed to look at the differences in airway responses between normal and asthmatic subjects following avoidance of deep inspiration before and/or after methacholine (10). Subjects completed four visits at the same time of day on four separate days within a 10-day period and, for those considered obese (ie, having a BMI $30 \mathrm{~kg} / \mathrm{m}^{2}$ or greater), another visit was required for body plethysmography, within one month of the first visit $(12,13)$.

During the first visit, subjects completed a standardized respiratory questionnaire to evaluate their pulmonary function, symptoms, family and personal medical history, atopy, smoking and environment. They had skin-prick tests with a battery of common airborne allergens and blood sampling for eosinophil cationic protein measurements.

To determine the frequency of deep inspirations in both groups when inspiratory manoeuvres were not restricted, the subjects were asked, while they were quietly seated on a chair, to breath normally through a facial mask for $20 \mathrm{~min}$. Their breathing pattern (volume and frequency of breaths) was recorded with a pneumotachograph.

A standard methacholine challenge with complete expiratory manoeuvres was performed with $\mathrm{FEV}_{1}$ measured $30 \mathrm{~s}, 90 \mathrm{~s}, 3$ min and $4 \mathrm{~min}$ from the end of methacholine inhalation (test A) (11). Baseline $\mathrm{FEV}_{1}$ had to be greater than $70 \%$ predicted. Briefly, after the baseline $\mathrm{FEV}_{1}$ measurements were made in triplicate, normal saline $(0.9 \%)$ was inhaled with a Wright nebulizer (Roxon, Canada), with a mouthpiece and filter on the expiratory line, followed by increasing doubling concentrations of methacholine. These were given for $2 \mathrm{~min}$ at $7 \mathrm{~min}$ intervals (ie, a $5 \mathrm{~min}$ interval between the end of one inhalation and the start of the next). The lowest $\mathrm{FEV}_{1}$ value postsaline was retained as the baseline value to estimate the percentage fall in $\mathrm{FEV}_{1}$ after each next step. The lowest $\mathrm{FEV}_{1}$ was measured after each concentration and the test was stopped either when there was a fall of $20 \%$ in $\mathrm{FEV}_{1}$ compared with the postsaline value or when the highest concentration of methacholine $(128 \mathrm{mg} / \mathrm{mL})$ had been administered. If the $\mathrm{FEV}_{1}$ fell between $17.5 \%$ and $20 \%$ from baseline, the methacholine challenge was stopped and the $\mathrm{PC}_{20}$ was extrapolated.

A second visit included a standard methacholine challenge, including the inhalation of normal saline $(0.9 \%)$, with $\mathrm{FEV}_{1}$ measured only at $3 \mathrm{~min}$ and $4 \mathrm{~min}$ and not at $30 \mathrm{~s}$ and $90 \mathrm{~s}$ (test B) from the end of saline and methacholine inhalations. At the end of the inhalation, the patient continued to avoid deep inspirations for 3 min, after which the first $\mathrm{FEV}_{1}$ was obtained.

For visits 3 and 4 , tests $C$ and $D$ were performed in a random order.

During test C, a single-dose methacholine test was performed. Baseline $\mathrm{FEV}_{1}$ was measured in triplicate and the lowest baseline value was retained to estimate the percentage fall in $\mathrm{FEV}_{1}$. There was no saline inhalation. The dose of methacholine chosen for the test was the final dose that had induced a $20 \%$ fall in $\mathrm{FEV}_{1}$ on test B, and $\mathrm{FEV}_{1}$ was measured only at $3 \mathrm{~min}$ and $4 \mathrm{~min}$ from the end of inhalation. At the end of the inhalation, the patient continued to avoid deep inspirations for $3 \mathrm{~min}$, after which the first $\mathrm{FEV}_{1}$ was obtained.

Test $\mathrm{D}$ was the same as test $\mathrm{C}$ except that after baseline measures of $\mathrm{FEV}_{1}$, the inhalation of the single dose of methacholine was preceded by $20 \mathrm{~min}$ of deep inspiration avoidance. During that period, the patient avoided any deep inspirations, including sneezing, coughing, laughing or any abnormal respiratory movement for $20 \mathrm{~min}$ before the onset of the inhalation of the single dose of methacholine. To ensure that no deep inspiration was taken, the respiratory volume was checked with a pneumotachograph.

The perception of symptoms during tests was evaluated on a perception scale from 0 to 10 (14). 


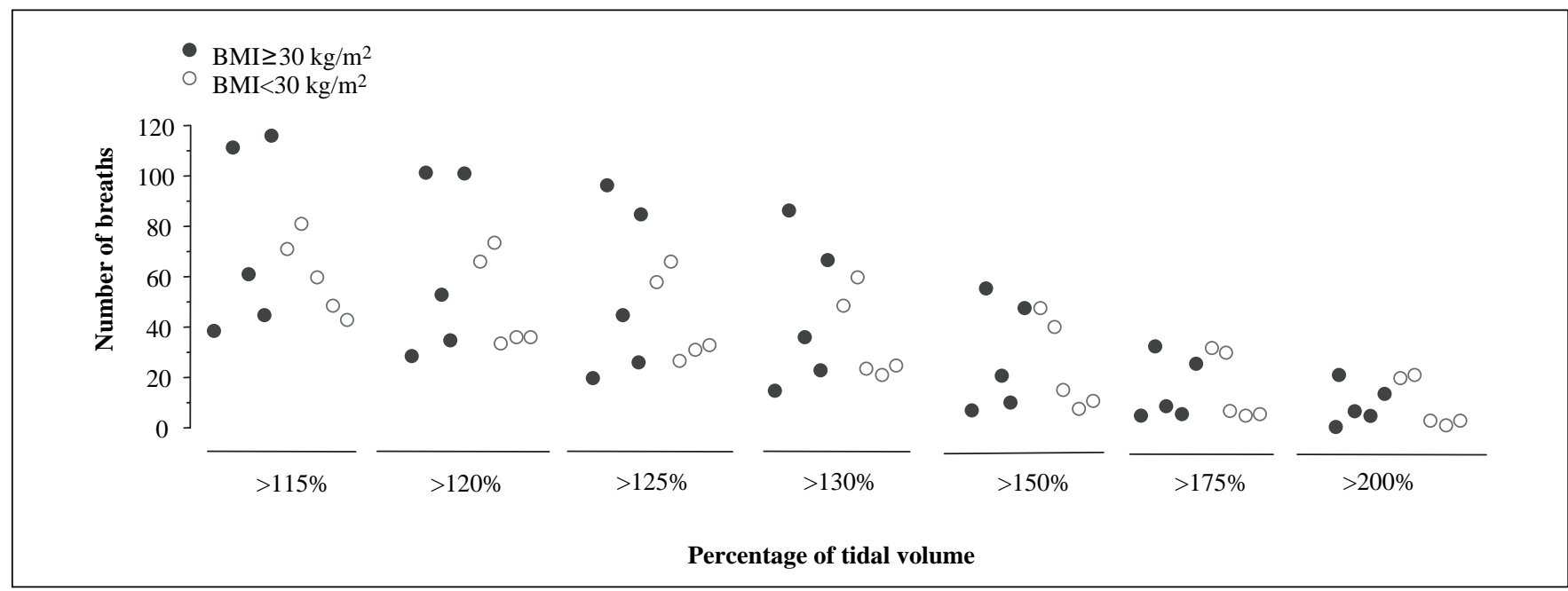

Figure 1) Numbers of breaths greater than 115\%,120\%, 125\%,130\%,150\%, 175\% or 200\% of mean tidal volume were not significantly different between subjects with a body mass index (BMI) less than $30 \mathrm{~kg} / \mathrm{m}^{2}$ and those with a BMI of $30 \mathrm{~kg} / \mathrm{m}^{2}$ or greater (P>0.05)

Body plethysmography was performed in subjects with a BMI of $30 \mathrm{~kg} / \mathrm{m}^{2}$ or greater, with measures of total lung capacity (TLC), functional residual capacity (FRC), residual volume (RV), inspiratory capacity, expiratory reserve volume (ERV), maximum inspiratory and expiratory pressures and airway resistance.

\section{Data analysis}

Results are expressed as mean \pm SEM values and as medians for respiratory symptoms. Baseline $\mathrm{FEV}_{1}$ for the four tests were compared using ANOVA. To analyze the effect of the time interval between the end of inhalation and the first $\mathrm{FEV}_{1}$ measurement, paired $t$-tests were used to compare $\log \mathrm{PC}_{20}$ and fall in $\mathrm{FEV}_{1}$ between tests $\mathrm{A}$ and $\mathrm{B}$, and to compare the fall in $\mathrm{FEV}_{1}$ between tests $\mathrm{C}$ and $\mathrm{D}$ to determine the influence of $20 \mathrm{~min}$ deep inspiration avoidance before methacholine inhalation (15).

Unpaired $t$-tests were used to compare the breathing pattern (total number of breaths in the $20 \mathrm{~min}$ period, total volume inspired, mean time duration/breath and mean volume/breath) between nonobese and obese subjects.

\section{RESULTS}

Breathing pattern during a 20 min period: A pilot study In a preliminary analysis of a group of five obese and five nonobese subjects, the spontaneous pattern of breathing during a 20 min period was examined to determine whether there were differences in the magnitude and frequency of deep inspirations between the two groups.

There were no significant differences between the means of the total number and total volume of breaths in $20 \mathrm{~min}$ in nonobese $(278 \pm 25$ and $45.2 \pm 12.3 \mathrm{~L}$, respectively) and obese subjects $(277 \pm 41$ and $36.5 \pm 5.4 \mathrm{~L}$, respectively; both $\mathrm{P}>0.05)$, between the mean duration of one breath $(4.5 \pm 0.4 \mathrm{~s}$ and $4.6 \pm 0.6 \mathrm{~s}$, respectively; $\mathrm{P}>0.05)$ and the mean volume inspired/breath $(0.161 \pm 0.040 \mathrm{~L}$ and $0.145 \pm 0.031 \mathrm{~L}$, respectively; $\mathrm{P}>0.05)$. The number of inspirations greater than mean tidal volume was not significantly different between obese and nonobese subjects (Figure 1, P>0.05). In this group of 10 subjects, volumes measured by body plethysmography were available for four obese and four nonobese subjects: the obese subjects had a lower FRC (a mean of $84 \%$ of predicted values compared with a mean of $101 \%$ in nonobese subjects) and mean TLC values were $94 \%$ and $108 \%$, respectively. For this reason, for the same amplitude of breath, they may not be as close to TLC as the nonobese subjects were.

\section{Subjects' characteristics and pulmonary function}

Subjects' characteristics are summarized in Table 1 . The 50 subjects participating in the study consisted of nine men (four with a BMI less than $30 \mathrm{~kg} / \mathrm{m}^{2}$ and five with a BMI of $30 \mathrm{~kg} / \mathrm{m}^{2}$ or greater) and 41 women (19 with a BMI less than $30 \mathrm{~kg} / \mathrm{m}^{2}$ and 22 with a BMI of $30 \mathrm{~kg} / \mathrm{m}^{2}$ or greater) aged 19 to 59 years (mean age 33.5 years), with a BMI ranging from $18 \mathrm{~kg} / \mathrm{m}^{2}$ to $49 \mathrm{~kg} / \mathrm{m}^{2}$. The mean BMI for the nonobese subjects was $22.3 \mathrm{~kg} / \mathrm{m}^{2}$ (range $18 \mathrm{~kg} / \mathrm{m}^{2}$ to $28 \mathrm{~kg} / \mathrm{m}^{2}$ ) and, for the obese subjects, it was $37.3 \mathrm{~kg} / \mathrm{m}^{2}$ (range $30 \mathrm{~kg} / \mathrm{m}^{2}$ to $49 \mathrm{~kg} / \mathrm{m}^{2}$ ). All subjects completed the study. The two groups were similar with regard to age and sex. None of the subjects in either the nonobese or obese group were currently smoking; five subjects in the nonobese group and eight in the obese group were ex-smokers for more than one year $(P>0.05)$, with respective medians of 4.0 pack-years and 2.4 pack-years $(\mathrm{P}>0.05)$, and medians of five and seven years of smoking cessation, respectively. The number of years of smoking was not significantly different between the groups.

Standard methacholine inhalation test (first $\mathrm{FEV}_{1}$ at $30 \mathrm{~s}$ )

There were no significant differences between control and obese subjects with regard to baseline $\mathrm{FEV}_{1}$ at first visit, with respective values of $103.9 \pm 2.3 \%$ and $97.9 \pm 3.0 \%$, nor in baseline airway responsiveness, with a geometric mean $\mathrm{PC}_{20}$ of $80.6 \mathrm{mg} / \mathrm{mL}$ and $56.3 \mathrm{mg} / \mathrm{mL}$, respectively $(\mathrm{P}>0.05)$. Baseline $\mathrm{FEV}_{1}$ and forced vital capacity (FVC) were normal in all subjects; they were not significantly different between the two groups, nor at baseline between the four tests in each subject $(P>0.05)$. There was a significant difference between sexes for baseline airway responsiveness, with a mean $\mathrm{PC}_{20}$ of $120 \mathrm{mg} / \mathrm{mL}$ in men and $50.4 \mathrm{mg} / \mathrm{mL}$ in women $(\mathrm{P}=0.03)$.

On body plethysmography, respiratory volumes of obese subjects were (as a percentage of predicted values): TLC $106 \pm 2 \%$, FRC $84 \pm 5 \%$, RV $110 \pm 5 \%$, inspiratory capacity $124 \pm 4 \%$ and 


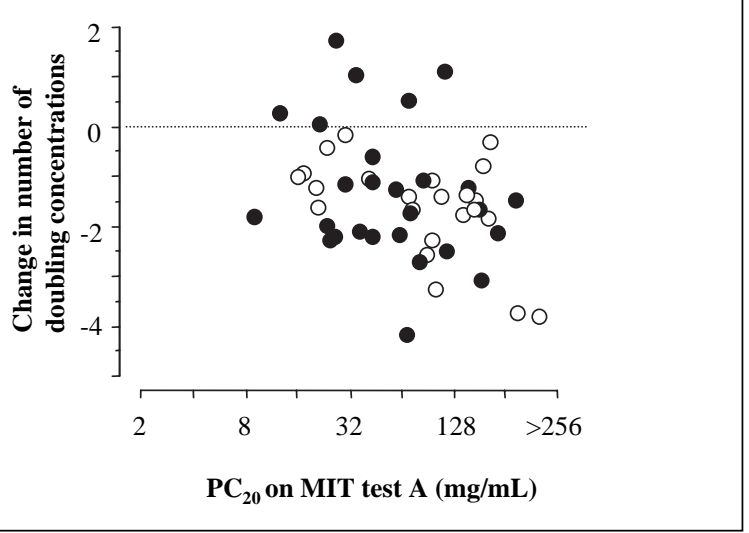

Figure 2) Spearman rank correlation $\left(r_{s}\right)$ between the change in the number of doubling concentrations of methacholine in tests $A(0.5 \mathrm{~min}$ before the first forced expiratory volume in $1 \mathrm{~s}\left[\mathrm{FEV}_{1}\right]$, multiple doses of methacholine and no period without deep inspiration before methacholine) and B (3 min before first $\mathrm{FEV}_{1}$, multiple doses of methacholine and no period without deep inspiration before methacholine), and the methacholine provocative concentration inducing a 20\% fall in $\mathrm{FEV}_{1}$ $\left(P_{20}\right)$ in test $A$. All subjects: $r_{s}=-0.331, P=0.02$; open circles indicate subjects with a body mass index less than $30 \mathrm{~kg} / \mathrm{m}^{2}: r_{s}=-0.468$, $P=0.028)$; closed circles indicate subjects with a body mass index of $30 \mathrm{~kg} / \mathrm{m}^{2}$ or greater: $r_{s}=-0.231, P>0.05$. MIT Methacholine inhalation test

ERV $57 \pm 6 \%$; and maximum pressures were: maximum inspiratory pressure $108 \pm 6 \%$ and maximum expiratory pressure $71 \pm 4 \%$. Mean airway resistance was $116 \pm 7 \%$ of predicted value. No significant differences were found between sexes for the various body plethysmography parameters, except for RV, which was higher in women $(117.5 \pm 8.2 \%$ of predicted values) than in men $(87.8 \pm 4.1 \%, \mathrm{P}=0.005)$.

\section{Methacholine responsiveness and symptom perception}

Baseline $\mathrm{FEV}_{1}$ (percentage of predicted values) did not vary significantly between the four tests for all subjects $(100.6 \%$, $100.9 \%, 100.6 \%$ and $101.2 \%, P>0.05)$, nor were there any differences in the baseline FVC between the four visits $(101.3 \%$, $101.6 \%, 101.4 \%$ and $101.7 \%$, for visits 1 to 4 , respectively, $\mathrm{P}>0.05)$. On the first methacholine challenge, there were no differences in the perception scores for breathlessness, cough, wheezing and phlegm production at baseline (absence of symptoms in both groups) and at $20 \%$ fall in $\mathrm{FEV}_{1}$ between the two groups $(\mathrm{P}>0.05)$. The obese group, however, had a significantly lower perception of chest tightness at $20 \%$ fall in $\mathrm{FEV}_{1}$, with a mean score of $0.8 \pm 0.3$ (median 0 , range 0 to 5.5 ) compared

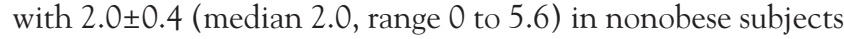
$(\mathrm{P}=0.009)$. There were no significant differences in respiratory symptoms evaluated at baseline (no symptoms) and at 20\% fall in $\mathrm{FEV}_{1}$ between nonobese and obese subjects on methacholine test $\mathrm{B}$ (all $\mathrm{P}>0.05)$.

\section{Effect of time of first $\mathrm{FEV}_{1}$ after methacholine inhalation} ( 3 min versus $30 \mathrm{~s}$ )

Geometric $\mathrm{PC}_{20}$ values for test $\mathrm{B}$ were $28.5 \mathrm{mg} / \mathrm{mL}$ in nonobese subjects and $21.5 \mathrm{mg} / \mathrm{mL}$ in obese subjects $(\mathrm{P}>0.05)$. In both groups, $\mathrm{PC}_{20}$ methacholine was significantly higher on test $\mathrm{A}$ than on test $\mathrm{B}$ (both groups, $\mathrm{P}<0.0001$ ), with the change in number of doubling concentrations of methacholine between

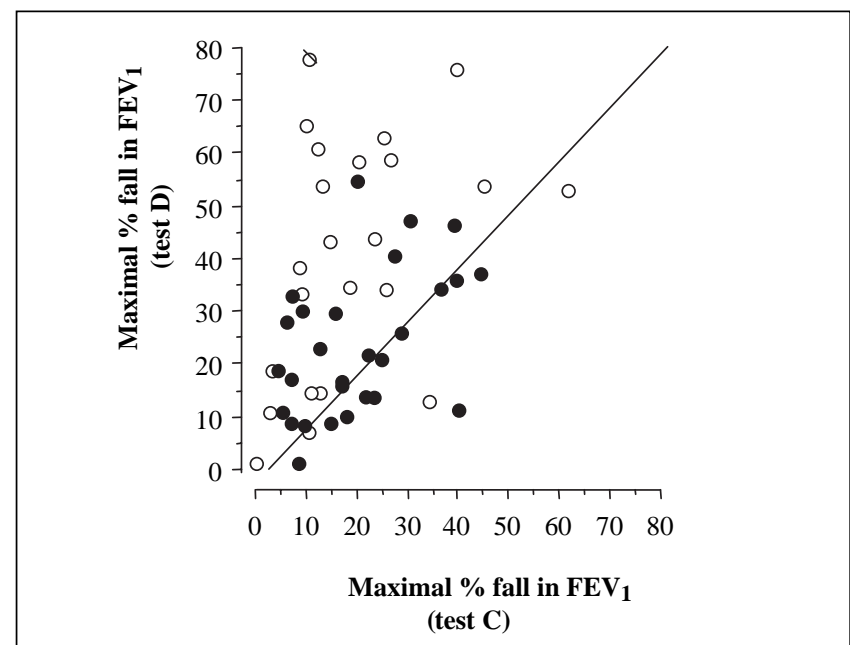

Figure 3) Maximum percentage fall in forced expiratory volume in $1 \mathrm{~s}$ $\left(F E V_{1}\right)$ in test $\mathrm{C}(3 \mathrm{~min}$ before first $\mathrm{FEV}$, single dose of methacholine and no period without deep inspiration before methacholine) and test $D$ (3 min before first $F E V_{1}$, single dose of methacholine and $20 \mathrm{~min}$ period without deep inspiration before methacholine). For a similar dose of methacholine, avoidance of deep inspirations before methacholine in test $D$ increased the fall in $\mathrm{FEV}$, compared with in test $\mathrm{C}$ in nonobese subjects (open circles indicate subjects with a body mass index less than $30 \mathrm{~kg} / \mathrm{m}^{2}$ $[P=0.0003]$ ), but had minimal effect on obese subjects (closed circles indicate subjects with a body mass index of $30 \mathrm{~kg} / \mathrm{m}^{2}$ or greater $[P>0.05])$. The fall in $F E V_{1}$ in test $D$ was significantly correlated with the fall in $F E V_{1}$ in test $\mathrm{C}$ in obese subjects (Spearman rank correlation $\left.\left[r_{s}\right]=0.47, P=0.02\right)$ but not in nonobese subjects $\left(r_{s}=0.27, P=0.20\right)$

the two tests being 1.50 for nonobese subjects and 1.39 for obese subjects ( $P>0.05$; Figure 2$)$. The change in the number of doubling concentrations of methacholine was not correlated with age or BMI $(\mathrm{P}>0.05)$, but was correlated with $\mathrm{PC}_{20}$ on test $\mathrm{A}$ in nonobese subjects (all subjects [ $\mathrm{n}=50$ ]: Spearman rank correlation $\left[r_{s}\right]=-0.331, P=0.02$; nonobese subjects: $r_{s}=-0.468$, $\mathrm{P}=0.028$; obese subjects: $\left.\mathrm{r}_{\mathrm{s}}=-0.231, \mathrm{P}>0.05\right)$. The higher the $\mathrm{PC}_{20}$ measured on test $\mathrm{A}$, the greater the drop in the doubling concentrations of methacholine for test $\mathrm{B}$.

Effect of deep inspiration avoidance before methacholine inhalation

When tests $\mathrm{C}$ (no deep inspiration avoidance before methacholine inhalation) and D (20 min of deep inspiration avoidance before methacholine inhalation) were compared, the maximum percentage falls in $\mathrm{FEV}_{1}$ were $20.3 \pm 2.9 \%$ (test $\mathrm{C}$ ) and $40.0 \pm 4.7 \%$ (test D) $(\mathrm{P}=0.0003)$ in nonobese subjects and $18.5 \pm 2.4 \%$ (test C) and 23.6 $\pm 2.7 \%$ (test D) $(\mathrm{P}>0.05)$ in obese subjects (Figure 3 ). The changes in fall in $\mathrm{FEV}_{1}$ between tests $\mathrm{C}$ and $\mathrm{D}$ were $19.7 \pm 4.7 \%$ and $5.1 \pm 2.6 \%$ in nonobese and obese subjects, respectively $(\mathrm{P}=0.007)$. The fall in $\mathrm{FEV}_{1}$ in test $\mathrm{D}$ was significantly correlated with the fall in $\mathrm{FEV}_{1}$ in test $\mathrm{C}$ in obese subjects $\left(r_{s}=0.47, P=0.02\right)$ but not in nonobese subjects $\left(r_{s}=0.27, \mathrm{P}=0.20\right)$.

\section{DISCUSSION}

The main finding of the present study is that in nonasthmatic obese subjects, contrary to what is observed in nonobese subjects, but similar to what has been previously described in asthmatic patients, there were no differences in the fall in $\mathrm{FEV}_{1}$ with or without previous avoidance of deep inspirations. This 
finding suggests the presence of altered airway protective mechanisms against bronchoconstricting agents, which could contribute to respiratory symptoms experienced by obese subjects. Furthermore, in both groups, the airway response to methacholine was similarly increased if the first postinhalation $\mathrm{FEV}_{1}$ was measured at $3 \mathrm{~min}$ instead of $0.5 \mathrm{~min}$.

This exploration of airway function was motivated by the previously observed increased prevalence of asthma and airway hyperresponsiveness (AHR) in obese subjects, and a marked improvement in asthma with weight reduction (1-4). We deliberately selected obese patients without asthma or AHR to explore any possible early change in airway function that could reflect an increased tendency to develop AHR over time or to develop asthma-like symptoms. Our observations suggest that the airways of obese subjects are not behaving normally, but instead like those of asthmatic patients, showing a loss of the bronchoprotection of deep inspiration manoeuvres.

The impairment of bronchial ASM relaxation following deep inspiration has been considered to result in increased airway responsiveness. However, the subjects studied had no asthma symptoms or frank AHR, possibly because their baseline level of airway responsiveness was too low for such an abnormality to translate into symptoms or AHR. This abnormality may nevertheless predispose those subjects, following progressive increases in airway responsiveness from antigenic exposure or other factors, to develop AHR at an earlier stage than nonobese subjects.

The mechanisms by which the bronchoprotection of deep inspiration manoeuvres is lost are uncertain, but this airway behaviour can be influenced by thickening or inflammation of the peribronchial adventitia, loss of lung elastic recoil or reduced tidal lung expansion (7). The last of these can occur with aging, obstructive or restrictive diseases, cervical spine injury or obesity.

Tidal stretching of the airway ASM is a potent bronchodilator and can detach cross bridges, reduce muscle stiffness and result in a decreased force generation and shortening (5). Obesity has been associated with a reduction in tidal volume (16) and, in obese subjects, tidal volume failed to increase during stresses such as exercise (17). It is possible that in obese subjects, deep inspiration does not result in the same effects on ASM as in normal subjects. In our study, the volume inspired per breath and the number of breaths/min were similar between nonobese and obese subjects. However, obese subjects were probably breathing at lower lung volumes than nonobese subjects, which seems to be confirmed by the low percentage predicted FRC and ERV values obtained by body plethysmography, an observation in keeping with previous findings showing that obesity leads to a reduction in FRC and $\operatorname{ERV}(18,19)$. In our initial analysis, as in previous studies, for which we had measurements of TLC and FRC in some of the obese and nonobese subjects, FRC was lower in obese subjects and normal in the others, whereas TLC was normal in both groups. For this reason, for the same amplitude of breath, the obese subjects may not have been as close to TLC as the nonobese subjects. The reduction in FRC and the low tidal volume may therefore alter ASM behaviour and the consequence of deep inspiration (20). As recently noted (5), the extent to which airway mechanical changes occur in subjects over a wide range of body weights and ages is an important research question. The above effects may be enhanced by breathing near the closing volume. In keeping with this hypothesis, a reduction in FRC, as found in obese subjects, has been associated with an increase in airway resistance and responsiveness to methacholine $(19,21)$. A low ERV has been associated with an abnormal distribution of ventilation and an increased closing volume (5).

A number of studies $(22,23)$ have shown an association between the symptoms of asthma and obesity in both adults and children. Asthma-like symptoms have also been reported (24) in obese subjects without AHR. The mechanisms by which these are induced are uncertain, but in a study (25) of obese healthy men with a normal $\mathrm{FEV}_{1}$ and $\mathrm{FEV}_{1} / \mathrm{FVC}$ greater than $80 \%$, the presence of resting dyspnea was associated with reduced maximum static expiratory mouth pressures, maximum voluntary ventilation and forced expiratory flow between $25 \%$ and $75 \%$ of vital capacity, suggesting peripheral airway dysfunction (25).

In our study, although the perception of symptoms at baseline was similar between obese and nonobese subjects, nonobese subjects had higher scores for perception of chest tightness at $\mathrm{PC}_{20}$ on the first methacholine inhalation test (test $\mathrm{A}$ ). The fact that similar scores were not observed after test $B$ could be the result of an adaptation due to the longer delay before the first $\mathrm{FEV}_{1}$ measurement or because that symptom had already been experienced during test $\mathrm{A}$. In obese subjects, the sensation of tightness may already be present and considered normal.

Furthermore, we observed a small, cumulative effect of methacholine that did not differ between obese and nonobese subjects. Such a cumulative effect has been previously reported, and we recently found it to be more marked in asthmatic patients than in normal subjects $(10,26)$.

Other mechanisms have been suggested to explain the relationship between asthma and obesity, such as neurogenic mechanisms, hormonal influences, an increased prevalence of gastroesophageal reflux or a predisposition to develop allergy and airway inflammation (5,6,27-29). A possible alteration to immune responses has been suggested for obese patients, who have increased concentrations of tumour necrosis factoralpha (TNF- $\alpha$ ), interleukin (IL)-1-beta, IL-5, IL-6, leptin and C-reactive protein (5,30-33). IL-6 and TNF- $\alpha$ have been found to be expressed during adiposis and correlate with total fat mass $(34,35)$. Leptin, a hormone produced by adipocytes, is present in greater quantities in overweight subjects and has been associated with an increased production of TNF- $\alpha$, IL- 6 and IL-12 from lipopolysaccharide-stimulated macrophages (33). The possibility that obesity is associated with an increased airway inflammatory response for a given stimulus is also supported by recent observations (36) that leptin increases ozone-induced neutrophil influx and eotaxin release in bronchoalveolar lavage of mice.

Finally, it has been proposed that obesity can increase the incidence of asthma, especially in women (37). We noted in the present study that airway responsiveness was higher in men than in women, and that RV, measured by body plethysmography, was significantly higher in women than in men, although we had mostly women in our study.

\section{CONCLUSIONS}

Nonasthmatic obese subjects with normal baseline airway responsiveness showed an abnormal airway behaviour in the form of a lack of change in airway response following avoidance of deep inspirations, as has been previously shown in asthmatic patients. This altered airway behaviour may contribute to the increased prevalence of asthma-like symptoms and AHR observed in obese subjects. 


\section{REFERENCES}

1. Moudgil H. Prevalence of obesity in asthmatic adults. BMJ 2000;321:448.

2. Camargo CA Jr, Weiss ST, Zhang S, Willett WC, Speizer FE. Prospective study of body mass index, weight change, and risk of adult-onset asthma in women. Arch Intern Med 1999;159:2582-8.

3. Stenius-Aarniala B, Poussa T, Kvarnstrom J, Gronlund EL, Ylikahri M, Mustajoki P. Immediate and long term effects of weight reduction in obese people with asthma: Randomised controlled study. BMJ 2000;320:827-32. (Erratum in 2000;320:984).

4. Dhabuwala A, Cannan RJ, Stubbs RS. Improvement in co-morbidities following weight loss from gastric bypass surgery. Obes Surg 2000;10:428-35.

5. Weiss ST, Shore S. Obesity and asthma: Directions for research. Am J Respir Crit Care Med 2004;169:963-8.

6. Tantisira KG, Weiss ST. Complex interactions in complex traits: Obesity and asthma. Thorax 2001;56(Suppl 2):64-73.

7. Fredberg JJ. Frozen objects: Small airways, big breaths, and asthma. J Allergy Clin Immunol 2000;106:615-24.

8. Skloot G, Permutt S, Togias A. Airway hyperresponsiveness in asthma: A problem of limited smooth muscle relaxation with inspiration. J Clin Invest 1995;96:2393-403.

9. Kapsali T, Permutt S, Laube B, Scichilone N, Togias A. Potent bronchoprotective effect of deep inspiration and its absence in asthma. J Appl Physiol 2000;89:711-20.

10. Simard B, Turcotte H, Cockcroft DW, Davis BE, Boulay ME, Boulet LP. Deep inspiration avoidance and methacholine response in normal subjects and patients with asthma. Chest 2005;127:135-42.

11. Juniper E, Cockcroft DW, Hargreave FE. Histamine and Methacholine Inhalation Tests: Tidal Breathing Method. Laboratory Procedure and Standardisation. Lund, Sweden: AB Draco, 1992.

12. The National Heart, Lung, and Blood Institute and The National Institute of Diabetes and Digestive and Kidney Diseases of the National Institutes of Health. Clinical guidelines on the identification, evaluation and treatment of overweight and obesity in adults: The evidence report. NIH Publication No 98-4083. Bethesda, Maryland: National Institutes of Health, 1998.

13. Clausen JL, ed. Pulmonary Function Testing: Guidelines and Controversies. New York: Academic Press, 1982:193-204.

14. Boulet LP, Leblanc P, Turcotte H. Perception scoring of induced bronchoconstriction as an index of awareness of asthma symptoms. Chest 1994;105:1430-3.

15. Zar JH. Biostatistical Analysis, 2nd edn. Englewood Cliffs, New Jersey: Prentice-Hall Inc, 1984:121-50.

16. Sampson MG, Grassino E. Load compensation in obese patients during quiet tidal breathing. J Appl Physiol 1983;55:1269-76.

17. Sakamoto S, Ishikawa K, Senda S, Nakajima S, Matsuo H. The effect of obesity on ventilatory response and anaerobic threshold during exercise. J Med Syst 1993;17:227-31.

18. Ray CS, Sue DY, Bray G, Hansen JE, Wasserman K. Effects of obesity on respiratory function. Am Rev Respir Dis 1983;128:501-6.

19. Zerah F, Harf A, Perlemuter L, Lorino H, Lorino AM, Atlan G. Effects of obesity on respiratory resistance. Chest 1993;103:1470-6.

20. Raboudi SH, Miller B, Butler JP, Shore SA, Fredberg JJ. Dynamically determined contractile states of airway smooth muscle. Am J Respir Crit Care Med 1998;158:S176-8.
21. Ding DJ, Martin JG, Macklem PT. Effects of lung volume on maximal methacholine-induced bronchoconstriction in normal humans. J Appl Physiol 1987;62:1324-30.

22. Jarvis D, Chinn S, Potts J, Burney P; European Community Respiratory Health Survey. Association of body mass index with respiratory symptoms and atopy: Results from the European Community Respiratory Health Survey. Clin Exp Allergy 2002;32:831-7.

23. Castro-Rodriguez JA, Holberg CJ, Morgan WJ, Wright AL, Martinez FD. Increased incidence of asthmalike symptoms in girls who become overweight or obese during the school years. Am J Respir Crit Care Med 2001;163:1344-9.

24. Schachter LM, Salome CM, Peat JK, Woolcock AJ. Obesity is a risk for asthma and wheeze but not airway hyperresponsiveness. Thorax 2001;56:4-8.

25. Sahebjami H. Dyspnea in obese healthy men. Chest 1998;114:1373-7.

26. Connolly MJ, Avery AJ, Walters EH, et al. The use of sequential doses of inhaled histamine in the measurement of bronchial responsiveness: Cumulative effect and distortion produced by shortening the test protocol. J Allergy Clin Immunol 1988;82:863-8.

27. Clements RH, Gonzalez QH, Foster A, et al. Gastrointestinal symptoms are more intense in morbidly obese patients and are improved with laparoscopic Roux-en-Y gastric bypass. Obes Surg 2003;13:610-4.

28. Oberle D, Von Kries R, Von Mutius E. Asthma and breast feeding. Thorax 2001;56:896.

29. Visser M, Bouter LM, McQuillan GM, Wener MH, Harris TB. Low-grade systemic inflammation in overweight children. Pediatrics 2001;107:E13.

30. Ziccardi P, Nappo F, Giugliano G, et al. Reduction of inflammatory cytokine concentrations and improvement of endothelial functions in obese women after weight loss over one year. Circulation 2002;105:804-9.

31. Bastard JP, Jardel C, Delattre J, Hainque B, Bruckert E, Oberlin F. Evidence for a link between adipose tissue interleukin- 6 content and serum C-reactive protein concentrations in obese subjects. Circulation 1999;99:2221-2.

32. Visser M, Bouter LM, McQuillan GM, Wener MH, Harris TB. Elevated C-reactive protein levels in overweight and obese adults. JAMA 1999;282:2131-5.

33. Loffreda S, Yang SQ, Lin HZ, et al. Leptin regulates proinflammatory immune responses. FASEB J 1998;12:57-65.

34. Tsigos C, Kyrou I, Chala E, et al. Circulating tumor necrosis factor alpha concentrations are higher in abdominal versus peripheral obesity. Metabolism 1999;48:1332-5.

35. Mohamed-Ali V, Goodrick S, Rawesh A, et al. Subcutaneous adipose tissue releases interleukin-6, but not tumor necrosis factor-alpha, in vivo. J Clin Endocrinol Metab 1997;82:4196-200.

36. Johnston RA, Schwartzman IN, Krishna Murthy CG, Shore SA. Effect of leptin on ozone-induced airway hyperreactivity and injury in C57BL/J6 mice. Am J Respir Crit Care Med 2002;165:A776. (Abst)

37. Chen Y, Dales R, Tang M, Krewski D. Obesity may increase the incidence of asthma in women but not in men: Longitudinal observations from the Canadian National Population Health Surveys. Am J Epidemiol 2002;155:191-7. 


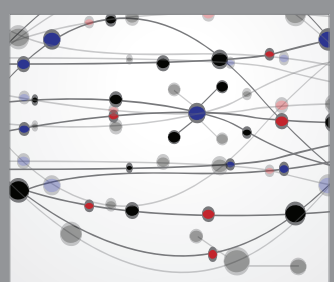

The Scientific World Journal
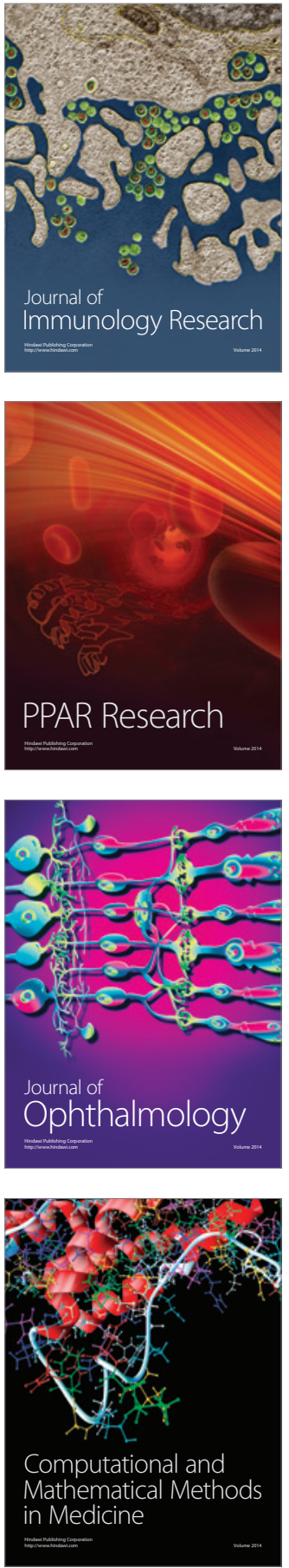

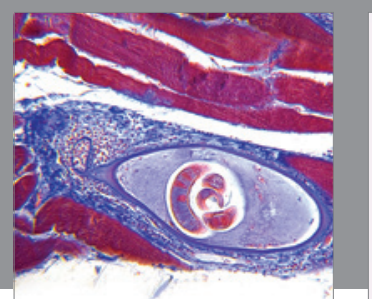

Gastroenterology Research and Practice

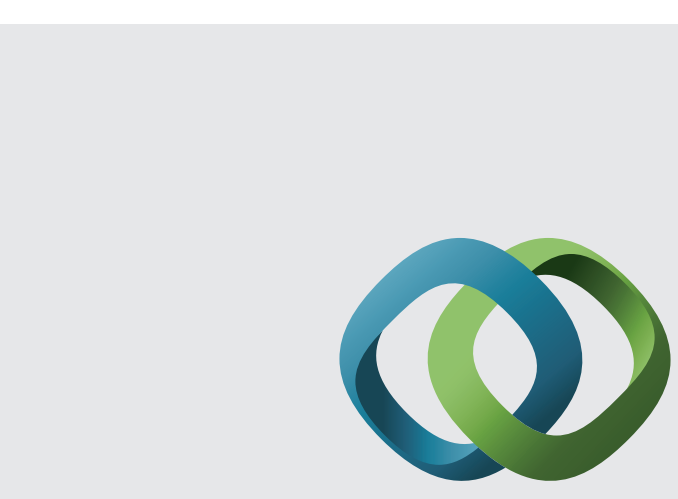

\section{Hindawi}

Submit your manuscripts at

http://www.hindawi.com
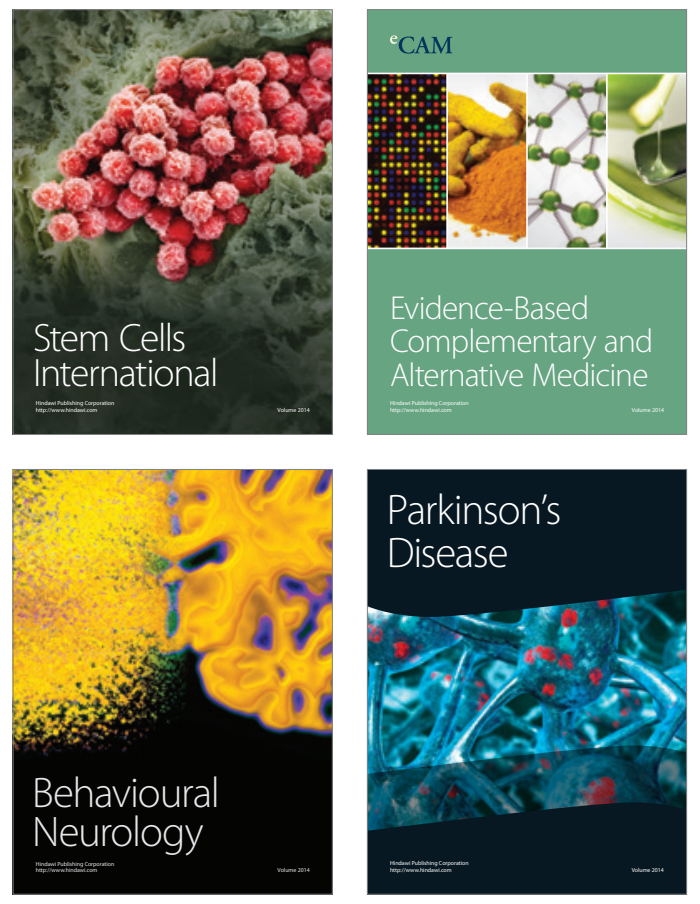
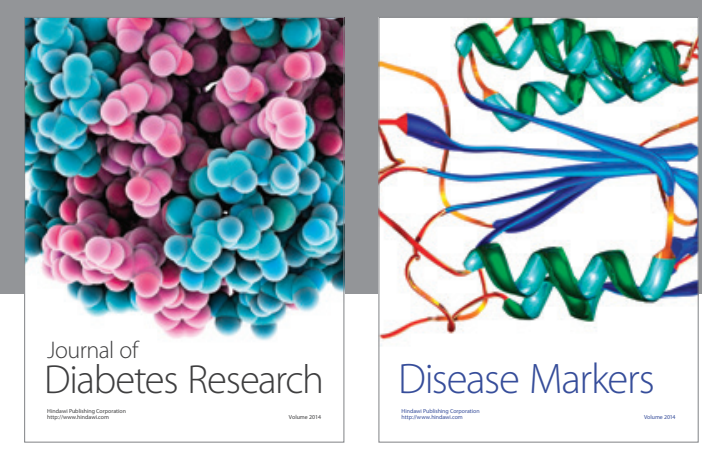

Disease Markers
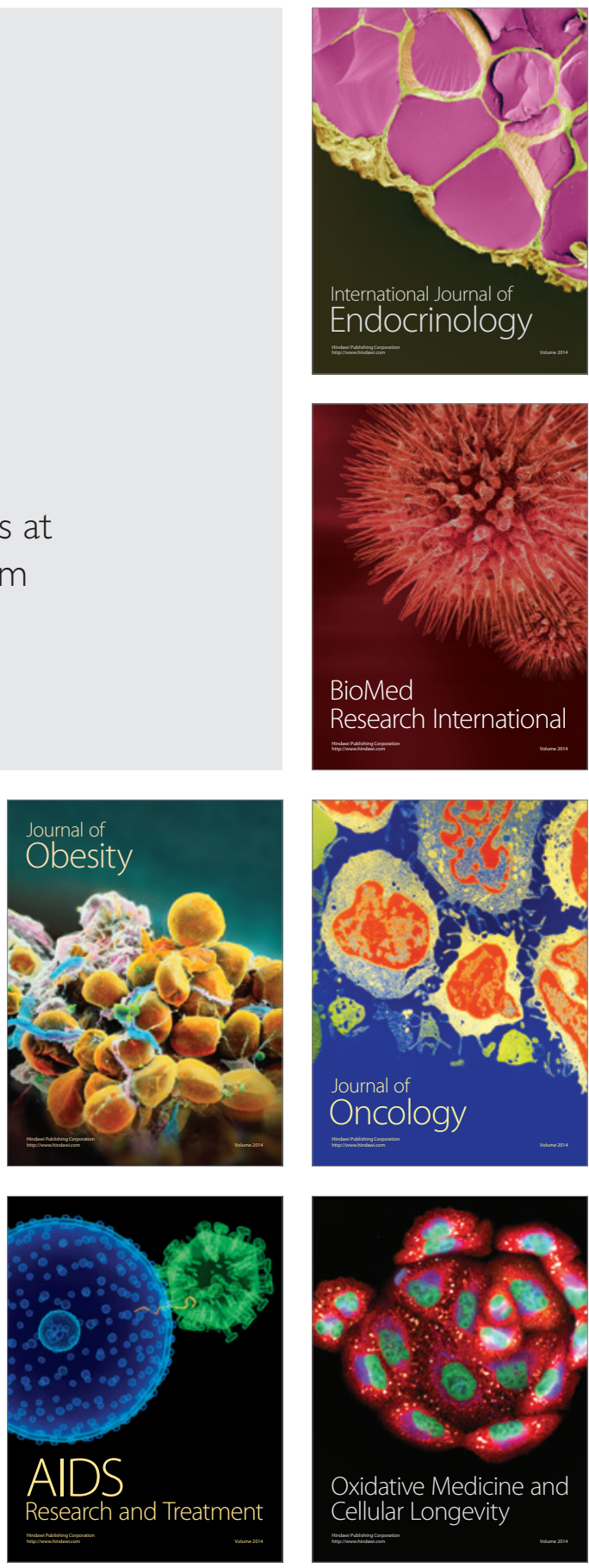